\title{
Stable oxygen isotope variability in two contrasting glacier river catchments in Greenland
}

\author{
Jacob C. Yde ${ }^{1}$, Niels T. Knudsen ${ }^{2}$, Jørgen P. Steffensen ${ }^{3}$, Jonathan L. Carrivick ${ }^{4}$, Bent Hasholt ${ }^{5}$, \\ Thomas Ingeman-Nielsen $^{6}$, Christian Kronborg ${ }^{2}$, Nicolaj K. Larsen ${ }^{2}$, Sebastian H. Mernild ${ }^{1,7}$, Hans Oerter ${ }^{8}$, \\ David H. Roberts ${ }^{9}$, and Andrew J. Russell ${ }^{10}$ \\ ${ }^{1}$ Faculty of Engineering and Science, Sogn og Fjordane University College, Sogndal, Norway \\ ${ }^{2}$ Department of Geoscience, University of Aarhus, Aarhus, Denmark \\ ${ }^{3}$ Centre for Ice and Climate, University of Copenhagen, Copenhagen, Denmark \\ ${ }^{4}$ School of Geography and water@leeds, University of Leeds, Leeds, UK \\ ${ }^{5}$ Department of Geosciences and Natural Resource Management, University of Copenhagen, Copenhagen, Denmark \\ ${ }^{6}$ Arctic Technology Centre, Technical University of Denmark, Kgs. Lyngby, Denmark \\ ${ }^{7}$ Antarctic and Sub-Antarctic Program, Universidad de Magallanes, Punta Arenas, Chile \\ ${ }^{8}$ Alfred Wegener Institute, Helmholtz Centre for Polar and Marine Research, Bremerhaven, Germany \\ ${ }^{9}$ Department of Geography, University of Durham, Durham, UK \\ ${ }^{10}$ School of Geography, Politics \& Sociology, Newcastle University, Newcastle upon Tyne, UK
}

Correspondence to: Jacob C. Yde (jacob.yde@ hisf.no)

Received: 15 April 2015 - Published in Hydrol. Earth Syst. Sci. Discuss.: 18 June 2015

Revised: 18 February 2016 - Accepted: 29 February 2016 - Published: 21 March 2016

\begin{abstract}
Analysis of stable oxygen isotope $\left(\delta^{18} \mathrm{O}\right)$ characteristics is a useful tool to investigate water provenance in glacier river systems. In order to attain knowledge on the diversity of $\delta^{18} \mathrm{O}$ variations in Greenlandic rivers, we examined two contrasting glacierised catchments disconnected from the Greenland Ice Sheet (GrIS). At the Mittivakkat Gletscher river, a small river draining a local temperate glacier in southeast Greenland, diurnal oscillations in $\delta^{18} \mathrm{O}$ occurred with a $3 \mathrm{~h}$ time lag to the diurnal oscillations in run-off. The mean annual $\delta^{18} \mathrm{O}$ was $-14.68 \pm 0.18 \%$ during the peak flow period. A hydrograph separation analysis revealed that the ice melt component constituted $82 \pm 5 \%$ of the total run-off and dominated the observed variations during peak flow in $\mathrm{Au}-$ gust 2004. The snowmelt component peaked between 10:00 and 13:00 local time, reflecting the long travel time and an inefficient distributed subglacial drainage network in the upper part of the glacier. At the Kuannersuit Glacier river on the island Qeqertarsuaq in west Greenland, the $\delta^{18} \mathrm{O}$ characteristics were examined after the major 1995-1998 glacier surge event. The mean annual $\delta^{18} \mathrm{O}$ was $-19.47 \pm 0.55 \%$. Despite large spatial variations in the $\delta^{18} \mathrm{O}$ values of glacier ice on the newly formed glacier tongue, there were no diurnal os-
\end{abstract}

cillations in the bulk meltwater emanating from the glacier in the post-surge years. This is likely a consequence of a tortuous subglacial drainage system consisting of linked cavities, which formed during the surge event. Overall, a comparison of the $\delta^{18} \mathrm{O}$ compositions from glacial river water in Greenland shows distinct differences between water draining local glaciers and ice caps (between -23.0 and $-13.7 \%$ ) and the GrIS (between -29.9 and $-23.2 \%$ ). This study demonstrates that water isotope analyses can be used to obtain important information on water sources and the subglacial drainage system structure that is highly desired for understanding glacier hydrology.

\section{Introduction}

There is an urgent need for improving our understanding of the controls on water sources and flow paths in Greenland. As in other parts of the Arctic, glacierised catchments in Greenland are highly sensitive to climate change (Milner et al., 2009; Blaen et al., 2014). In recent decades freshwater run-off from the Greenland Ice Sheet (GrIS) to adjacent 
seas has increased significantly (Hanna et al., 2005, 2008; Bamber et al., 2012; Mernild and Liston, 2012), and the total ice mass loss from the GrIS contributes with $0.33 \mathrm{~mm}$ sea level equivalent $\mathrm{yr}^{-1}$ to global sea level rise (1993-2010; Vaughan et al., 2013). In addition, ice mass loss from local glaciers (i.e. glaciers and ice caps peripheral to the GrIS; Weidick and Morris, 1998) has resulted in a global sea level rise of $0.09 \mathrm{~mm}$ sea level equivalent $\mathrm{yr}^{-1}$ (1993-2010; Vaughan et al., 2013). The changes in run-off are coupled to recent warming in Greenland (Hanna et al., 2012, 2013; Mernild et al., 2014), an increasing trend in precipitation and changes in precipitation patterns (Bales et al., 2009; Mernild et al., 2015a), and a decline in albedo (Bøggild et al., 2010; Tedesco et al., 2011; Box et al., 2012; Yallop et al., 2012; Mernild et al., 2015b). Also, extreme surface melt events have occurred in recent years (Tedesco et al., 2008, 2011; van As et al., 2012), and in July 2012 more than $97 \%$ of the GrIS experienced surface melting (Nghiem et al., 2012; Keegan et al., 2014). In this climate change context, detailed catchmentscale studies on water source and water flow dynamics are urgently needed to advance our knowledge of the potential consequences of future hydrological changes in Greenlandic river catchments.

Analysis of stable oxygen isotopes is a very useful technique to investigate water provenance in glacial river systems. Stable oxygen isotopes are natural conservative tracers in low-temperature hydrological systems (e.g. Moser and Stichler, 1980; Gat and Gonfiantini, 1981; Haldorsen et al., 1997; Kendall et al., 2014). Consequently, oxygen isotopes can be applied to determine the timing and origin of changes in water sources and flow paths because different water sources often have isotopically different compositions due to their exposure to different isotopic fractionation processes. Since the 1970s, this technique has been widely used for hydrograph separation (Dinçer et al., 1970). Most often a conceptual two-component mixing model is applied, where an old-water component (e.g. groundwater) is mixed with a new-water component (e.g. rain or snowmelt), assuming that both components have spatial and temporal homogeneous compositions. The general mixing model is given by the equation

$$
Q C=Q_{1} C_{1}+Q_{2} C_{2}+\ldots
$$

where the discharge $Q$ and the isotopic value $C$ are equal to the sum of their components. This simplified model has limitations when a specific precipitation event is analysed because the water isotope composition in precipitation (new water) may vary considerably during a single event (e.g. McDonnell et al., 1990) and changes in contributions from secondary old-water reservoirs may occur (e.g. Hooper and Shoemaker, 1986). Nevertheless, water isotope mixing models still provide valuable information on spatial differences in hydrological processes on diurnal to annual timescales (Kendall et al., 2014).

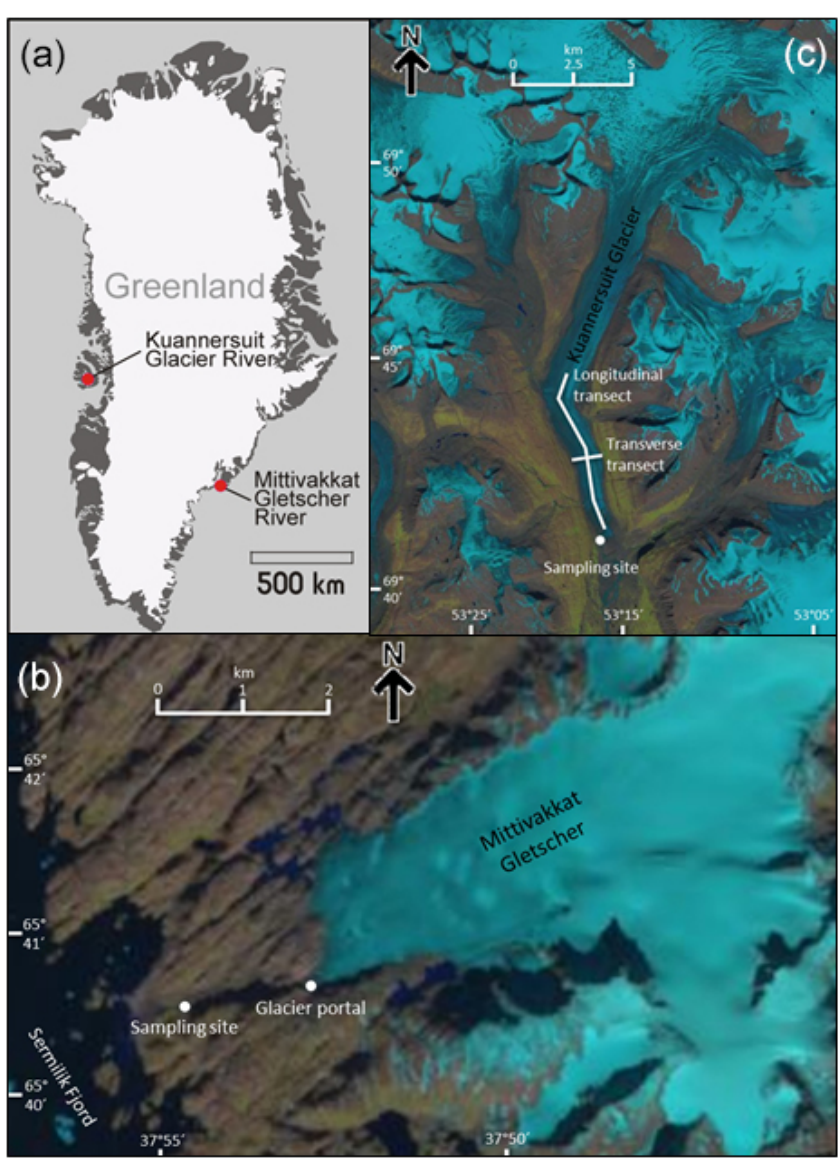

Figure 1. Location map (a) of the study areas at (b) the Mittivakkat Gletscher river, southeast Greenland (image from Landsat 8 OLI on 3 September 2013), and at (c) the Kuannersuit Glacier river, west Greenland (image from Landsat 8 OLI on 8 July 2014).

In glacier-fed river systems, the principal water sources to bulk run-off derive from ice melt, snowmelt, rainfall and groundwater components. Depending on the objectives of the study and on the environmental setting, hydrograph separation of glacial rivers has been based on assumed endmember isotope mixing between two or three prevailing components (Behrens et al., 1971, 1978; Fairchild et al., 1999; Mark and Seltzer, 2003; Theakstone, 2003; Yde and Knudsen, 2004; Mark and McKenzie, 2007; Yde et al., 2008; Bhatia et al., 2011; Kong and Pang, 2012; Ohlanders et al., 2013; Blaen et al., 2014; Dahlke et al., 2014; Hindshaw et al., 2014; Meng et al., 2014; Penna et al., 2014; Rodriguez et al., 2014; Zhou et al., 2014). As glacierised catchments vary in size, altitudinal range, hypsometry, degree of glaciation, and thermal and morphological glacier types, isotope hydrograph separation often requires that the primary local controls on run-off generation are identified in order to analyse the variability in isotope time series. In detailed studies it may even be necessary to divide a main component, such as ice melt, into several ice facies sub-components (Yde and Knudsen, 2004). 
However, in highly glacierised catchments the variability in oxygen isotope composition is generally controlled by seasonal snowmelt and ice melt with episodic inputs of rainwater, whereas contributions from shallow groundwater flow may become important in catchments, where glaciers comprise a small proportion of the total area (e.g. Blaen et al., 2014).

In this study, we examine the stable oxygen isotope composition in two Greenlandic glacier river systems, namely the Mittivakkat Gletscher river $\left(13.6 \mathrm{~km}^{2}\right)$, which drains a local non-surging glacier in southeast Greenland, and the Kuannersuit Glacier river $\left(258 \mathrm{~km}^{2}\right)$, which drains a local glacier on the island Qeqertarsuaq, west Greenland. The latter experienced a major glacier surge event in 1995-1998. Our aim is to gain insights into the variability and controls of the oxygen isotope composition in contrasting glacierised river catchments located peripheral to the GrIS (i.e. the river systems do not drain meltwater from the GrIS). Besides a study by Andreasen (1984) at the glacier Killersuaq in west Greenland, this is the first study of oxygen isotope dynamics in rivers draining glacierised catchments peripheral to the GrIS.

\section{Study sites}

\subsection{Mittivakkat Gletscher river, Ammassalik Island, southeast Greenland}

Mittivakkat Gletscher $\left(65^{\circ} 41^{\prime} \mathrm{N}, 37^{\circ} 50^{\prime} \mathrm{W}\right)$ is the largest glacier complex on Ammassalik Island, southeast Greenland (Fig. 1). The entire glacier covered an area of $26.2 \mathrm{~km}^{2}$ in 2011 (Mernild et al., 2012) and has an altitudinal range between 160 and $880 \mathrm{~m}$ a.s.1. (Mernild et al., 2013a). Bulk meltwater from the glacier drains primarily westwards to the proglacial Mittivakkat Valley and flows into the Sermilik Fjord. The sampling site is located at a hydrometric station $1.3 \mathrm{~km}$ down-valley from the main subglacial meltwater portal. The hydrological catchment has an area of $13.6 \mathrm{~km}^{2}$, of which $9.0 \mathrm{~km}^{2}$ is glacierised $(66 \%)$. The maritime climate is Low Arctic with annual precipitation ranging from 1400 to $1800 \mathrm{~mm}$ water equivalent (w.e.) $\mathrm{yr}^{-1}$ (1998-2006) and a mean annual air temperature (MAAT) at $515 \mathrm{~m}$ a.s.l. of $-2.2^{\circ} \mathrm{C}$ (1993-2011; updated from Mernild et al., 2008a). There are no observations of contemporary permafrost in the area, and the proglacial vegetation cover is sparse.

The glacier has undergone continuous recession since the end of the Little Ice Age (Knudsen et al., 2008; Mernild et al., 2011). In recent decades the recession has accelerated and the glacier has lost approximately $29 \%$ of its volume between 1994 and 2012 (Yde et al., 2014), and surface mass balance measurements indicate a mean thinning rate of $1.01 \mathrm{~m}$ w.e. $\mathrm{yr}^{-1}$ between 1995-1996 and 2011-2012 (Mernild et al., 2013a). Similar to other local glaciers in the Ammassalik region, Mittivakkat Gletscher is severely out of contemporary climatic equilibrium (Mernild et al., 2012,
Table 1. Summary of $\delta^{18} \mathrm{O}$ mean and range in bulk water samples at the Mittivakkat Gletscher river.

\begin{tabular}{llrrrr}
\hline Year & Campaign period & $n$ & $\delta^{18} \mathrm{O}_{\text {mean }}$ & $\delta^{18} \mathrm{O}_{\max }$ & $\delta^{18} \mathrm{O}_{\min }$ \\
\hline 2003 & 11-13 Aug & 4 & -14.42 & -14.30 & -14.65 \\
2004 & 8-22 Aug & 103 & -14.55 & -14.19 & -14.91 \\
2005 & 30 May-12 Jun & 29 & -14.71 & -14.35 & -15.16 \\
& 23-26 Jul & 19 & -14.10 & -13.74 & -14.41 \\
& 11-19 Aug & 44 & -14.73 & -14.13 & -16.43 \\
2006 & 11-16 Aug & 11 & -14.85 & -14.26 & -15.42 \\
2007 & 2-10 Aug & 17 & -14.69 & -14.07 & -15.11 \\
2008 & 29 May-11 Jun* & 28 & -16.92 & -15.92 & -17.35 \\
& 10-16 Aug & 15 & -14.84 & -14.47 & -15.20 \\
2009 & 8-16 Aug & 17 & -14.88 & -14.56 & -15.13 \\
\hline
\end{tabular}

* Collected at a sampling site ca. $500 \mathrm{~m}$ closer to the glacier front

2013b) and serves as a representative location for studying the impact of climate change on glacierised river catchments in southeast Greenland (e.g. Mernild et al., 2008b, 2015b; Bárcena et al., 2010, 2011; Kristiansen et al., 2013; Lutz et al., 2014).

\subsection{Kuannersuit Glacier river, Qeqertarsuaq, west Greenland}

Kuannersuit Glacier $\left(69^{\circ} 46^{\prime} \mathrm{N}, 53^{\circ} 15^{\prime} \mathrm{W}\right)$ is located in central Qeqertarsuaq (formerly Disko Island), west Greenland (Fig. 1). It is an outlet glacier descending from the Sermersuaq ice cap and belongs to the Qeqertarsuaq-Nuussuaq surge cluster (Yde and Knudsen, 2007). In 1995, the glacier started to surge down the Kuannersuit Valley with a frontal velocity up to $70 \mathrm{~m}$ per day (Larsen et al., 2010). By the end of 1998 or beginning of 1999, the surging phase terminated and the glacier went into its quiescent phase, which is presumed to last more than 100 years (Yde and Knudsen, 2005a). The 1995-1998 surge of Kuannersuit Glacier is one of the largest land-terminating surge events ever recorded; the glacier advanced $10.5 \mathrm{~km}$ down-valley, and approximately $3 \mathrm{~km}^{3}$ of ice was moved to form a new glacier tongue (Larsen et al., 2010).

The Kuannersuit Glacier river originates from a portal at the western side of the glacier terminus, and the sampling site is located $200 \mathrm{~m}$ down-stream (Yde et al., 2005a). The catchment area has an altitude range of 100-1650 $\mathrm{m}$ a.s.l. and covers $258 \mathrm{~km}^{2}$, of which Kuannersuit Glacier constitutes $103 \mathrm{~km}^{2}$ of the total glacierised area of $168 \mathrm{~km}^{2}$ (Yde and Knudsen, 2005a). The valley floor consists of unvegetated outwash sediment; dead-ice deposits; and ice-cored, vegetated terraces. The proglacial area of the catchment is situated in the continuous permafrost zone (Yde and Knudsen, 2005b), and the climate is polar continental (Humlum, 1999). There are no meteorological observations from the area, but at the coastal town of Qeqertarsuaq (formerly Godhavn), located $50 \mathrm{~km}$ to the southwest, the MAAT was -2.7 and $-1.7^{\circ} \mathrm{C}$ in 2011 and 2012, respectively (Cappelen, 2013). 
Table 2. Summary of $\delta^{18} \mathrm{O}$ mean and range in bulk water samples at the Kuannersuit Glacier river.

\begin{tabular}{llrrrr}
\hline Year & $\begin{array}{l}\text { Campaign } \\
\text { period }\end{array}$ & $n$ & $\delta^{18} \mathrm{O}_{\text {mean }}$ & $\delta^{18} \mathrm{O}_{\max }$ & $\delta^{18} \mathrm{O}_{\min }$ \\
\hline 2000 & 24-27 Jul & 21 & -19.80 & -19.47 & -19.97 \\
2001 & 14-31 Jul & 109 & -19.25 & -17.82 & -19.55 \\
2002 & 14-15 Jul & 21 & -19.01 & -18.75 & -19.39 \\
2003 & 18-26 Jul & 27 & -20.43 & -19.03 & -21.88 \\
2005 & 19-24 Jul & 2 & -19.42 & -19.32 & -19.51 \\
\hline
\end{tabular}

\section{Methods}

\subsection{Sampling protocol and isotope analyses}

In total, 287 oxygen isotope samples were collected from the Mittivakkat Gletscher river during the years 2003-2009 (Table 1). Most of the sampling campaigns were conducted in August at the end of the peak flow period (i.e. the summer period with relatively high run-off). The most intensively sampled period was from 8 to 22 August 2004, where sampling was conducted with a $4 \mathrm{~h}$ frequency supplemented by short periods of higher frequency sampling. In the years 2005 and 2008 , meltwater was also collected during the early melt season (i.e. the period before the subglacial drainage system is well established) to evaluate the seasonal variability in the $\delta^{18} \mathrm{O}$ signal. An additional 40 river samples were collected for multi-sampling tests.

During five field seasons in July 2000, 2001, 2002, 2003 and 2005 , a total of 180 oxygen isotope samples were collected from the Kuannersuit Glacier river (Table 2), and another 44 river samples were collected for multi-sampling tests. In addition, 13 ice samples were obtained along a longitudinal transect at the centreline of the newly formed glacier tongue with $500 \mathrm{~m}$ sampling increments in July 2001, and 23 ice samples were collected along a transverse transect with $50 \mathrm{~m}$ sampling increments in July 2003. The transverse transect crossed the longitudinal transect at a distance of $3250 \mathrm{~m}$ from the glacier front. Seven samples of rainwater were collected in a Hellmann rain gauge located in the vicinity of the glacier terminus in July 2002.

All water samples were collected manually in $20 \mathrm{~mL}$ vials. Ice samples were collected in $250 \mathrm{~mL}$ polypropylene bottles or plastic bags before being slowly melted and decanted to $20 \mathrm{~mL}$ vials. The vials were stored in cold $\left(\sim 5^{\circ} \mathrm{C}\right)$ and dark conditions to avoid fractionation related to biological activity.

The relative deviations $(\delta)$ of water isotope compositions $\left({ }^{18} \mathrm{O} /{ }^{16} \mathrm{O}\right)$ were expressed in per mil $(\% o)$ relative to Vienna Standard Mean Ocean Water (0\%; Coplen, 1996). The stable oxygen isotope analyses were performed at the Niels Bohr Institute, University of Copenhagen, Denmark, using mass spectrometry with an instrumental precision of $\pm 0.1 \%$ in the oxygen isotope ratio $\left(\delta^{18} \mathrm{O}\right)$ value.
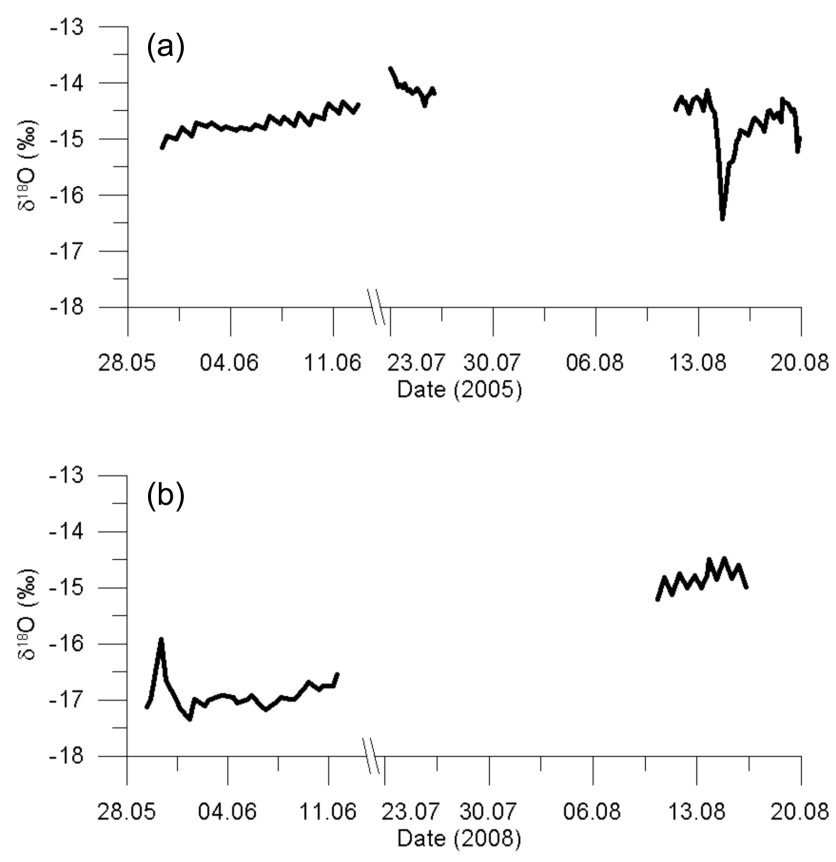

Figure 2. $\delta^{18} \mathrm{O}$ time series of meltwater draining Mittivakkat Gletscher in (a) 2005 and (b) 2008.

The oxygen isotope data from this study are available in the Supplement (Tables S1-S6).

\subsection{Multi-sample tests}

In the Mittivakkat Gletscher river, we conducted three multisample tests at 14:00 local time on 9, 15 and 21 August 2004 to determine the combined uncertainty related to sampling and analytical error. During the multi-sample tests samples were collected simultaneously (within $3 \mathrm{~min}$ ). The tests show standard deviations of $0.08(n=25), 0.06(n=5)$ and $0.04 \%$ o $(n=10)$, respectively, which are lower than the instrumental precision $( \pm 0.1 \%$ ) .

In the Kuannersuit Glacier river, multi-sample tests were conducted in 2001, 2002 and 2003, showing a standard deviation of $\pm 0.16(n=5), \pm 0.13(n=17)$ and $\pm 0.44 \%$ o $(n=22)$, respectively. The multi-sample test in 2003 showed a standard deviation significantly larger than the instrumental precision $( \pm 0.1 \% \circ)$. This deviation cannot be explained by the presence of a few high $\delta^{18} \mathrm{O}$ values. The most plausible explanation is that the glacier run-off was not well mixed in 2003, possibly because different parts of the drainage system merged close to the glacier portal.

\subsection{Run-off measurements}

Stage-discharge relationships were used to determine runoff at each study site. The accuracy of individual run-off measurements is within $\pm 7 \%$ (e.g. Herschy, 1999). For details on run-off measurements we refer to Hasholt and 


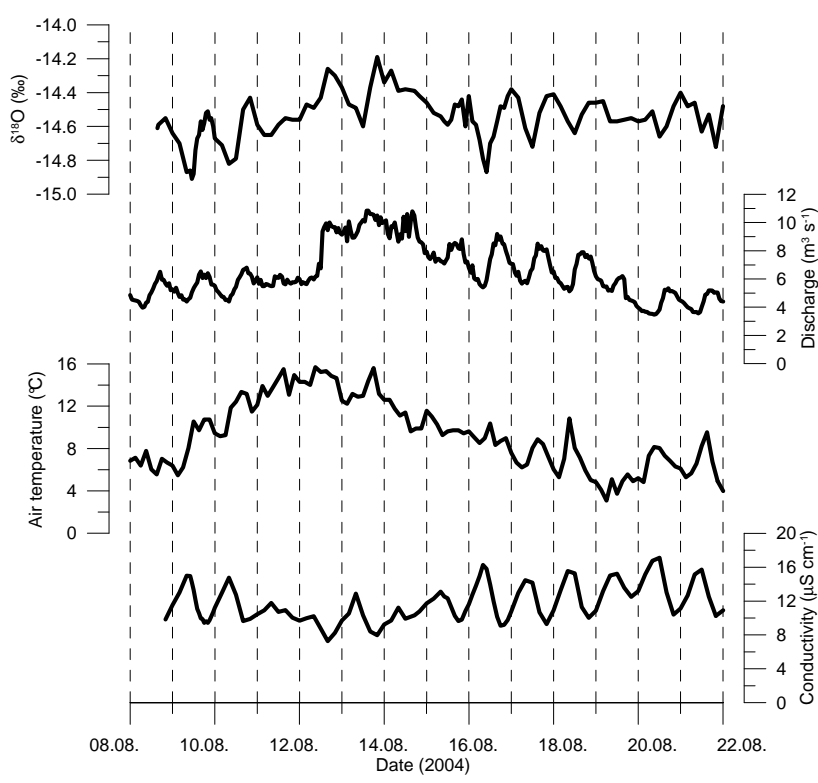

Figure 3. Time series of $\delta^{18} \mathrm{O}$, discharge, air temperature and electric conductivity in meltwater draining Mittivakkat Gletscher during the period 8-21 August 2004.

Mernild (2006) for the Mittivakkat Gletscher river and Yde et al. (2005a) for the Kuannersuit Glacier river. In short, at the Mittivakkat Gletscher river the run-off measurements were conducted at a hydrometric monitoring station located after the braided river system had changed into a single river channel about $500 \mathrm{~m}$ from the river outlet. The station was installed in August 2004 and recorded water stage every $10 \mathrm{~min}$ during the peak flow period. At the Kuannersuit Glacier river the run-off measurements were obtained at a hydrometric monitoring station installed in July 2001 at a location where the river merges to a single channel. Water stage was recorded every hour during the peak flow period. The station was destroyed during the spring river break-up in 2002.

\section{Results}

\section{1 $\delta^{18} \mathrm{O}$ characteristics}

At the Mittivakkat Gletscher river, the early melt season is characterised by an increasing trend in $\delta^{18} \mathrm{O}$. In 2005 the $\delta^{18} \mathrm{O}$ values in the early melt season were coincident with the $\delta^{18} \mathrm{O}$ values during the peak flow period (Fig. 2a; Table 1). This indicates that the onset of ice melt commenced before the early melt season sampling campaign. In contrast, the 2008 onset of ice melt was delayed, and snowmelt totally dominated the bulk composition of the river water except on 30 May 2008, when a rainfall event $(19 \mathrm{~mm}$ in the nearby town of Tasiilaq, located $10 \mathrm{~km}$ to the southeast of the Mittivakkat Gletscher river catchment; Cappelen, 2013) caused a positive peak in $\delta^{18} \mathrm{O}$ of $\sim 1 \%$ (Fig. 2b). This difference

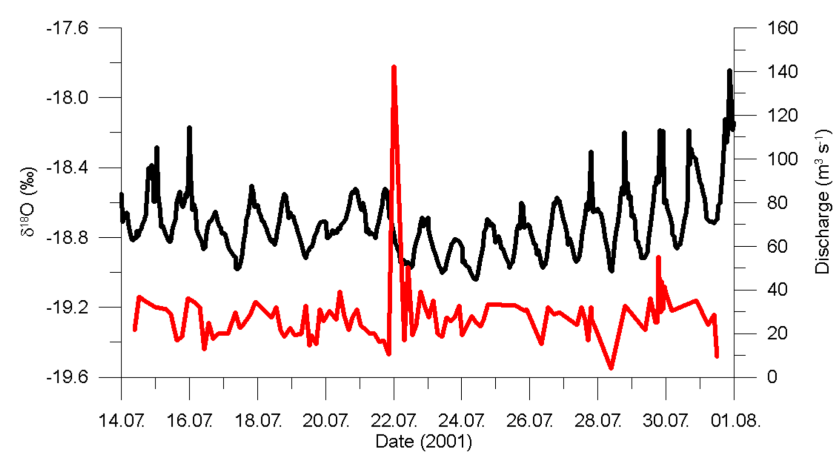

Figure 4. Time series of $\delta^{18} \mathrm{O}$ (red curve) and discharge (black curve) in the Kuannersuit Glacier river during the period 14-31 July 2001.

between the early ablation seasons in 2005 and 2008 is consistent with the meteorological record from Tasiilaq, which shows that the region received a large amount of precipitation in May $2008(140 \mathrm{~mm})$ compared to a dry May 2005 (17 mm; Cappelen, 2013). Episodic effects on $\delta^{18} \mathrm{O}$ by precipitation seem common throughout the ablation season. For instance, another short-term change occurred on 14-15 August 2005 (Fig. 2a), when a negative peak in $\delta^{18} \mathrm{O}$ of $\sim 2 \%$ coincided with a snowfall event (14 mm in Tasiilaq; Cappelen, 2013) and subsequent elevated contribution from snowmelt.

During the peak flow periods, the mean annual $\delta^{18} \mathrm{O}$ was $-14.68 \pm 0.18 \%$ o (Table 1 ). We use the 2004 time series to assess oxygen isotope dynamics in the Mittivakkat Gletscher river during the peak flow period when the subglacial drainage system is assumed to be well established, transporting the majority of meltwater in a channelised network (Mernild, 2006). In Fig. 3, the $2004 \delta^{18} \mathrm{O}$ time series is shown together with run-off (at the hydrometric station), air temperature (at a nunatak at $515 \mathrm{~m}$ a.s.l.) and electrical conductivity (at the hydrometric station; corrected to $25^{\circ} \mathrm{C}$ ). There was no precipitation during the entire sampling period, except for some drizzle on 8 August prior to the collection of the first sample. The time series shows characteristic diurnal variations in $\delta^{18} \mathrm{O}$ composition, e.g. on $9-10$ and 1618 August 2004. However, the diurnal pattern was severely disturbed at around 03:00 on 11 August 2004. The hydrograph shows that during the falling limb the diurnal trend in run-off was interrupted, coinciding with an air temperature increase and a change in $\delta^{18} \mathrm{O}$ from decreasing to slightly increasing values. The run-off stayed almost constant until a rapid $39 \%$ increase in run-off occurred at 13:00 on $12 \mathrm{Au}-$ gust 2004, accompanied by an increase in $\delta^{18} \mathrm{O}$ and decrease in electrical conductivity. Thereafter, run-off remained at an elevated level for more than 2 days before returning to a diurnal oscillation of run-off. Hydrograph separation of water sources is a helpful tool to elucidate the details of this event (see Sect. 4.3).

In the Kuannersuit Glacier river, the sample-weighted mean annual $\delta^{18} \mathrm{O}$ was $-19.47 \pm 0.55 \%$ o during the peak 


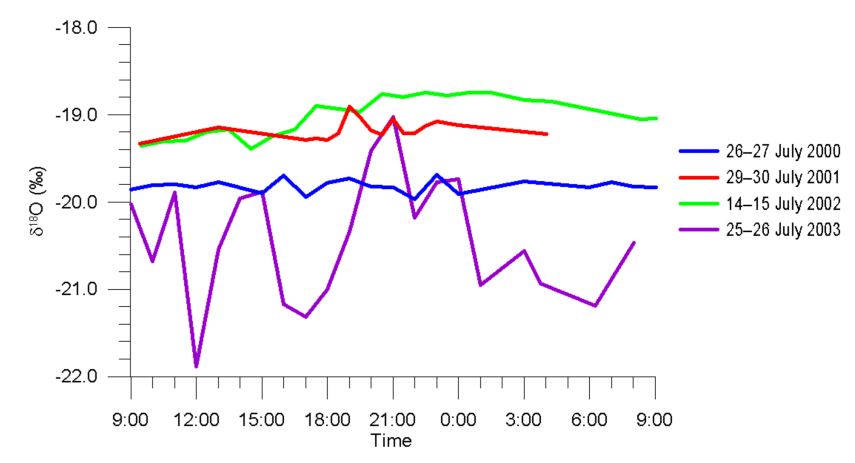

Figure 5. Diurnal $\delta^{18} \mathrm{O}$ variations in the Kuannersuit Glacier river on studied days in July in the post-surge years 2000-2003. Multisample tests conducted in 2001, 2002 and 2003 showed standard deviations of $\pm 0.16, \pm 0.13$ and $\pm 0.44 \%$ o, respectively.

flow period (a sample-weighted value is applied because the number of samples per year deviated between 2 and 109). In Fig. 4, the variations in $\delta^{18} \mathrm{O}$ are presented together with run-off for the period 14-31 July 2001. The 2001 run-off measurements showed diurnal oscillations with minimums around 10:00-12:00 and maximums at 19:00-20:00, correlating well with reversed oscillations in solutes (Yde et al., 2005a) and poorly with suspended sediment concentrations (Knudsen et al., 2007). However, the variability of $\delta^{18} \mathrm{O}$ did not correlate with run-off or any of these variables. While some of the episodic damming and meltwater release events appear as peaks on the run-off time series, the peaks in the $\delta^{18} \mathrm{O}$ time series coincided with rainfall events (e.g. on the nights of 21 and 29 July 2001). Besides these episodic peaks, a lack of diurnal fluctuations in $\delta^{18} \mathrm{O}$ characterised the $\delta^{18} \mathrm{O}$ time series.

Figure 5 shows the diurnal $\delta^{18} \mathrm{O}$ variations during 4 days in July without rainfall in the years 2000-2003. There were no diurnal oscillations in 2000, 2001 and 2002. In 2003, the fluctuations were much larger than in the preceding years, but the highest $\delta^{18} \mathrm{O}(-19.03 \%$ ) was measured at 21:00, and low $\delta^{18} \mathrm{O}$ prevailed during the night $(\sim-21.0 \%)$. This diurnal variability was also reflected in the standard deviations of the measurements taken over the $24 \mathrm{~h}$ periods, which increased from \pm 0.07 in 2000 to $\pm 0.11, \pm 0.23$ and $\pm 0.70 \%$ o in 2001, 2002 and 2003, respectively. The corresponding diurnal amplitudes for 2000-2003 were 0.28, 0.42, 0.64 and $2.85 \%$, respectively. Although these measurements from a single day each year are insufficient to represent the conditions for the entire peak flow period, they may indicate postsurge changes in the structure of subglacial hydrological system which are worth addressing in detail in future studies of the hydrological system of surging glaciers.

\section{$4.2 \quad \delta^{18} \mathrm{O}$ endmember components}

On Mittivakkat Gletscher, three snow pits $(0.1 \mathrm{~m}$ sampling increments) were excavated at different altitudes in May 1999, showing a mean $\delta^{18} \mathrm{O}$ composition of $-16.5 \pm 0.6 \%$ o (hereafter the uncertainty of $\delta^{18} \mathrm{O}$ is given by the standard deviation) in winter snow (Dissing, 2000). The range of individual samples in each snow pit varied between -14.5 and $-19.5 \%$ ( 269 ma.s.l.; mean $\delta^{18} \mathrm{O}$ $=-16.24 \pm 1.35 ; n=36),-13.8$ and $-21.2 \%$ (502 $\mathrm{m}$ a.s.l.; mean $\left.\delta^{18} \mathrm{O}=-17.11 \pm 2.13 ; n=21\right)$, and -11.9 and $-21.6 \%$ (675 m a.s.l.; mean $\delta^{18} \mathrm{O}=-16.18 \pm 2.70 ; n=26$; Dissing, 2000). Also, two ice-surface $\delta^{18} \mathrm{O}$ records of 2.84 and $1.05 \mathrm{~km}$ in length (10 m sampling increments) were obtained from the glacier terminus towards the equilibrium line (Boye, 1999). The glacier ice $\delta^{18} \mathrm{O}$ ranged between -15.0 and $-13.3 \%$ with a mean $\delta^{18} \mathrm{O}$ of $-14.1 \%$ (Boye, 1999), and the theoretical altitudinal effect (Dansgaard, 1964) of higher $\delta^{18} \mathrm{O}$ towards the equilibrium line altitude (ELA) was not observed. The reasons for an absence of a $\delta^{18} \mathrm{O}$ lapse rate are most likely the limited size and altitudinal range (160$880 \mathrm{~m}$ a.s.l.) of Mittivakkat Gletscher, but ice dynamics, ice age and meteorological conditions such as frequent inversion (Mernild and Liston, 2010) may also have an impact. The $\delta^{18} \mathrm{O}$ of summer rain has not been determined in this region, but at the coastal village of Ittoqqortoormiit, located $\sim 840 \mathrm{~km}$ to the north of Mittivakkat Gletscher, observations show monthly mean $\delta^{18} \mathrm{O}$ in rainwater of $-12.8,-9.1$ and $-8.8 \%$ in June, July and August, respectively (data available from the International Atomic Energy Agency database WISER). Based on these observations it is evident that endmember snowmelt has a relatively low $\delta^{18} \mathrm{O}$ compared to endmember ice melt and that these two water source components can be separated. Contributions from rainwater will likely result in episodic increase in the $\delta^{18} \mathrm{O}$ of bulk meltwater.

In the Kuannersuit Glacier river system, the glaciological setting differed from the Mittivakkat Gletscher river system. During the surge event of Kuannersuit Glacier, the glacier front advanced from $\sim 500$ down to 100 ma.s.l., while a significant part of the glacier surface in the accumulation area was lowered by more than $100 \mathrm{~m}$ to altitudes below the ELA ( 1100-1300 m a.s.l.). A helicopter survey in July 2002 revealed that the post-surge accumulation area ratio was less than $20 \%$ (Yde et al., 2005a). Hence, we assume that the primary post-surge water source during the peak flow period is ice melt, particularly from ablation of the new glacier tongue. The mean $\delta^{18} \mathrm{O}$ value of glacier ice collected along the longitudinal and transverse transects was $-20.5 \pm 1.0 \%$ o $(n=36)$. This is consistent with $\delta^{18} \mathrm{O}$ values of glacier ice located near the glacier front, showing mean $\delta^{18} \mathrm{O}$ of $-19.4 \pm 0.9 \%$ o $(n=20)$ in a section with debris layers formed by thrusting and $-19.8 \pm 1.1 \%$ o $(n=37)$ in a section without debris layers (Larsen et al., 2010). In contrast to the setting at the Mittivakkat Gletscher river, it was likely that another ice melt component in bulk run-off from Kuannersuit Glacier comprised water from several ice facies sub-component sources with various $\delta^{18} \mathrm{O}$ values and spatial variability. During the surge event, a thick debris-rich basal 


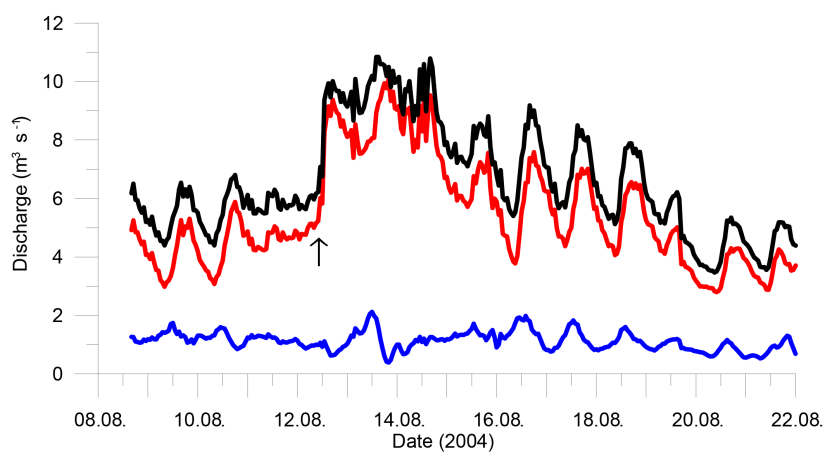

Figure 6. Hydrograph showing the separation of the discharge in the Mittivakkat Gletscher river (black curve) into an ice melt component (red curve) and a snowmelt component (blue curve) during the period 8-21 August 2004. The error of the ice melt and snowmelt components depends on the constant endmember estimates and the cubic spline interpolation. The arrow indicates the onset of the abrupt change in discharge.

ice sequence was formed beneath the glacier and exposed along the glacier margins and at the glacier terminus (Yde et al., 2005b; Roberts et al., 2009; Larsen et al., 2010). The basal ice consisted of various genetic ice facies, where different isotopic fractionation processes during the basal ice formation resulted in variations in the $\delta^{18} \mathrm{O}$ composition. The $\delta^{18} \mathrm{O}$ in massive stratified ice was $-16.6 \pm 1.9 \%$ o $(n=10)$; in laminated stratified ice it was $-19.6 \pm 0.7 \%$ o $(n=9)$; and in dispersed ice it was $-18.8 \pm 0.6 \%$ o $(n=41$; Larsen et al., 2010). Also, during the termination of the surge event in winter 1998-1999, proglacial naled was stacked into $\sim 3 \mathrm{~m}$ thick sections of thrust-block naled at the glacier front, as the glacier advanced into the naled (Yde and Knudsen, 2005b; Yde et al., 2005b; Roberts et al., 2009). Naled is an extrusive ice assemblage formed in front of the glacier by rapid freezing of winter run-off and/or proglacial upwelling water mixed with snow. A profile in a thrust-block naled section showed a $\delta^{18} \mathrm{O}$ of $-20.1 \pm 0.5 \%$ o $(n=60$; excluding an outlier polluted by rainwater; Yde and Knudsen, 2005b). With regard to the endmember compositions of snowmelt and rainwater at the Kuannersuit Glacier river, it was not possible to access snow on the upper part of the glacier, so no $\delta^{18} \mathrm{O}$ values on snowmelt were measured. Rainwater was collected during rainfall events in July 2002, showing a wide range in $\delta^{18} \mathrm{O}$ between -18.78 and $-6.57 \%$ and a median $\delta^{18} \mathrm{O}$ of $-10.32 \pm 4.49 \%$ o $(n=7$; Table S6).

\subsection{Hydrograph separation}

The conditions for conducting hydrograph separation during the peak flow period were different for the two study catchments. At the Mittivakkat Gletscher river it was possible to distinguish between the $\delta^{18} \mathrm{O}$ values of endmember ice melt and snowmelt components, and there were diurnal oscillations in $\delta^{18} \mathrm{O}$. In contrast, the available data from the Kuan- nersuit Glacier river did not allow hydrograph separation in the years following the surge event. Here, there were no diurnal oscillations in $\delta^{18} \mathrm{O}$, and the composition and importance of the snowmelt component were unknown. Hence, we will continue by using the 2004 time series to construct a two-component hydrograph separation (Eq. 1) during a period without precipitation for the Mittivakkat Gletscher river.

First, we apply time-series cubic spline interpolation to estimate $\delta^{18} \mathrm{O}$ at $1 \mathrm{~h}$ time-step increments, matching the temporal resolution of the run-off observations. This approach allows a better assessment of the diurnal $\delta^{18} \mathrm{O}$ signal. For instance, a best-fit analysis shows that overall the $\delta^{18} \mathrm{O}$ signal lags $3 \mathrm{~h}$ behind run-off $\left(r^{2}=0.66\right.$; linear correlation without lag shows $r^{2}=0.58$ ), indicating the combined effect of the two primary components, snowmelt and ice melt, on the $\delta^{18} \mathrm{O}$ variations. The diurnal amplitude in $\delta^{18} \mathrm{O}$ ranged between 0.11 (11 August 2004) and 0.49\%o (16 August 2004). However, there was no statistical relation between diurnal $\delta^{18} \mathrm{O}$ amplitude and daily air temperature amplitude $\left(r^{2}=0.28\right)$, indicating that other forcings than variability in surface melting may have a more dominant effect on the responding variability in $\delta^{18} \mathrm{O}$.

Based on the assumption that snowmelt and ice melt reflect their endmember $\delta^{18} \mathrm{O}$ compositions $(-16.5$ and $-14.1 \%$, respectively), a hydrograph showing contributions from snowmelt and ice melt is constructed for the 2004 sampling period (Fig. 6). The ice melt component constituted $82 \pm 5 \%$ (where \pm indicates the standard deviation of the hourly estimates) of the total run-off and dominated the observed variations in total run-off $\left(r^{2}=0.99\right)$. This is expected late in the peak flow period, when the subglacial drainage mainly occurs in a channelised network in the lower part of the glacier (Mernild, 2006). The slightly decreasing trend in the daily snowmelt component was likely a consequence of the diminishing snow cover on the upper part of the glacier. The snowmelt component peaked around 10:00-13:00 each day, reflecting the long distance from the melting snowpack to the proglacial sampling site and the possible existence of an inefficient distributed subglacial drainage network in the upper part of the glacier.

The most likely reason for an abrupt change in glacial runoff, such as the one observed during the early morning of 11 August 2004 followed by the sudden release of water $34 \mathrm{~h}$ later, is a roof collapse causing ice-block damming of a major subglacial channel. The hydrograph separation (Fig. 6) shows that the proportion between ice melt and snowmelt remained almost constant after the event commenced, indicating that the bulk water derived from a well-mixed part of the drainage system, which was unaffected by the large diurnal variation in ice melt generation. This suggests that the functioning drainage network transported meltwater from the upper part of the glacier with limited connection to the drainage network in the lower part. Meanwhile, ice melt was stored in a dammed section of the subglacial network located in the lower part of the glacier and suddenly released when the 
dam broke at 13:00 on 12 August (Fig. 6). In the following hours ice melt comprised up to $94 \%$ of the total run-off. On 13 August the snowmelt component peaked at noon but then dropped markedly, and in the evening it only constituted $4 \%$ of the total run-off. On 14 August there were still some minor disturbances in the lower drainage network, but from 15 August the drainage system had stabilised and the characteristic diurnal glacionival oscillations had taken over (Figs. 3 and 6).

\subsection{Uncertainties in $\delta^{18} \mathrm{O}$ hydrograph separation models}

The accuracy of endmember hydrograph separation models is limited by the uncertainties of the estimated values of each endmember component, the uncertainty of the cubic spline interpolation at each data point and the uncertainty of $\delta^{18} \mathrm{O}$ in the river. While the uncertainty of $\delta^{18} \mathrm{O}$ in the river is likely to be relatively small, the uncertainties of each endmember component must be kept in mind (e.g. Cable et al., 2011; Arendt et al., 2015). The assumption of discrete values of each endmember component is unlikely to reflect the spatial and temporal changes in bulk $\delta^{18} \mathrm{O}$ of snowmelt, ice melt and rainwater. For instance, Raben and Theakstone (1998) found a seasonal increase in mean $\delta^{18} \mathrm{O}$ in snow pits on Austre Okstindbreen, Norway, and episodic events such as passages of storms (e.g. McDonnell et al., 1990; Theakstone, 2008) or melting of fresh snow in the late ablation season may cause temporal changes in one component. Also, snowpacks have a non-uniform layered structure with heterogeneous $\delta^{18} \mathrm{O}$ composition, and isotopic fractionation is likely to occur as melting progresses and the snowpack is mixed with rainwater (e.g. Raben and Theakstone, 1998; Lee et al., 2010). It is also difficult to assess how representative snow pits and ice transects are for the bulk $\delta^{18} \mathrm{O}$ value of each component. Spatial differences in $\delta^{18} \mathrm{O}$ may exist within and between snow pits, but the overall effect on the isotopic composition of the water leaving the melting snowpack at a given time is unknown.

\subsection{Longitudinal and transverse $\delta^{18} \mathrm{O}$ transects}

Glacier ice samples were collected on the surface of Kuannersuit Glacier to gain insights into the spatial variability of $\delta^{18} \mathrm{O}$ on the newly formed glacier tongue. Both the longitudinal and transverse transects showed large spatial fluctuations in $\delta^{18} \mathrm{O}$ (Fig. 7). The longitudinal transect was sampled along the centreline but showed unsystematic fluctuations on a $500 \mathrm{~m}$ sampling increment scale. In contrast, the transverse transect, which was sampled $3250 \mathrm{~m}$ up-glacier with $50 \mathrm{~m}$ increments, showed a more systematic trend where relatively high $\delta^{18} \mathrm{O}$ values were observed along both lateral margins. From the centre towards the western margin an increasing trend of $0.46 \%$ per $100 \mathrm{~m}$ prevailed, whereas the eastern central part showed large fluctuations in $\delta^{18} \mathrm{O}$ be-
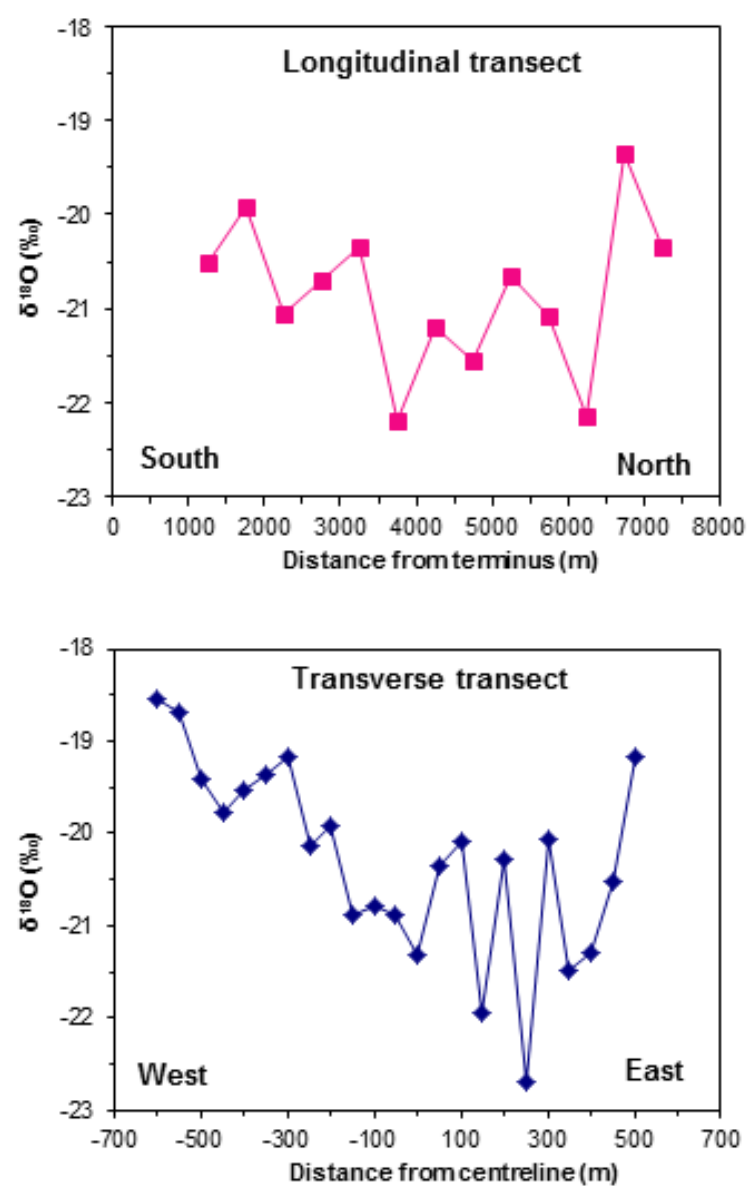

Figure 7. Variations in $\delta^{18} \mathrm{O}$ of glacier ice along a longitudinal transect and a transverse transect on Kuannersuit Glacier. The transverse transect crosses the longitudinal transect at a distance of $3250 \mathrm{~m}$ from the glacier terminus.

tween -22.69 and $-20.08 \%$. The total range of measured $\delta^{18} \mathrm{O}$ in glacier ice along the transverse transect was $4.14 \%$. A possible explanation of this marked spatial variability may be that the ice forming the new tongue derived from different pre-surge reservoirs on the upper part of the glacier. If so, it is very likely that the marginal glacier ice was formed at relatively low elevations (high $\delta^{18} \mathrm{O}$ signal), whereas the glacier ice in the western central part mainly derived from high-elevation areas of Sermersuaq ice cap (low $\delta^{18} \mathrm{O}$ signal). At present, there are only a few comparable studies on transverse variations in $\delta^{18} \mathrm{O}$ across glacier tongues. Epstein and Sharp (1959) found a decrease in $\delta^{18} \mathrm{O}$ towards the margins of Saskatchewan Glacier, Canada. Hambrey (1974) measured a similar decrease in $\delta^{18} \mathrm{O}$ towards the margins of Charles Rabots Bre, Norway, in an upper transect, whereas a lower transect showed wide unsystematic variations in $\delta^{18} \mathrm{O}$. Hambrey (1974) concluded that in the upper transect the marginal ice derived from higher altitudes than ice in the centre, whereas in the lower transect the wide variations were related to structural complexity of the glacier. However, both 
Table 3. Maximum and minimum $\delta^{18} \mathrm{O}$ in glacier rivers.

\begin{tabular}{|c|c|c|c|c|c|c|}
\hline Site & Sampling period & Latitude & Longitude & Maximum $(\% o)$ & Minimum (\%o) & Reference \\
\hline \multicolumn{7}{|l|}{ Greenland } \\
\hline Mittivakkat Gletscher (local glacier) & 2003-2009 & $65^{\circ} 41^{\prime} \mathrm{N}$ & $37^{\circ} 50^{\prime} \mathrm{W}$ & -13.7 & -17.4 & This paper \\
\hline Kuannersuit Glacier (ice cap outlet) & 2000-2005 & $69^{\circ} 46^{\prime} \mathrm{N}$ & $53^{\circ} 15^{\prime} \mathrm{W}$ & -17.8 & -21.9 & This paper \\
\hline Hobbs Gletscher (local glacier) & 2004 & $65^{\circ} 46^{\prime} \mathrm{N}$ & $38^{\circ} 11^{\prime} \mathrm{W}$ & -14.7 & -15.1 & Yde (unpublished data) \\
\hline Imersuaq (GrIS outlet) & 2000 & $66^{\circ} 07^{\prime} \mathrm{N}$ & $49^{\circ} 54^{\prime} \mathrm{W}$ & -24.3 & -29.9 & Yde and Knudsen (2004) \\
\hline Killersuaq (ice cap outlet) & $1982-1983$ & $66^{\circ} 07^{\prime} \mathrm{N}$ & $50^{\circ} 10^{\prime} \mathrm{W}$ & -19.5 & -23.0 & Andreasen (1984) \\
\hline Leverett Glacier (GrIS outlet) & 2009 & $67^{\circ} 04^{\prime} \mathrm{N}$ & $50^{\circ} 10^{\prime} \mathrm{W}$ & -23.2 & -24.2 & Hindshaw et al. (2014) \\
\hline Isunnguata Sermia (GrIS outlet) & 2008 & $67^{\circ} 11^{\prime} \mathrm{N}$ & $50^{\circ} 20^{\prime} \mathrm{W}$ & $-26.2^{\mathrm{a}}$ & & Yde (unpublished data) \\
\hline "N" Glacier (GrIS outlet) & 2008 & $68^{\circ} 03^{\prime} \mathrm{N}$ & $50^{\circ} 16^{\prime} \mathrm{W}$ & $\sim-23.3$ & $\sim-28.3$ & Bhatia et al. (2011) \\
\hline \multicolumn{7}{|l|}{ Scandinavia and Svalbard } \\
\hline Austre Okstindbreen, Norway & 1980-1995 & $66^{\circ} 00^{\prime} \mathrm{N}$ & $14^{\circ} 10^{\prime} \mathrm{E}$ & -11.8 & -14.4 & Theakstone (2003) \\
\hline Storglaciären, Sweden & $2004 \& 2011$ & $67^{\circ} 54^{\prime} \mathrm{N}$ & $18^{\circ} 38^{\prime} \mathrm{E}$ & -10.9 & -15.9 & Dahlke et al. (2014) \\
\hline Austre Grønfjordbreen, Svalbard & 2009 & $77^{\circ} 56^{\prime} \mathrm{N}$ & $14^{\circ} 19^{\prime} \mathrm{E}$ & $-11.2^{\mathrm{a}}$ & & Yde et al. (2012) \\
\hline Dryadbreen, Svalbard & 2012 & $78^{\circ} 09^{\prime} \mathrm{N}$ & $15^{\circ} 27^{\prime} \mathrm{E}$ & -13.0 & -15.5 & Hindshaw et al. (2016) \\
\hline Longyearbreen, Svalbard & 2004 & $78^{\circ} 11^{\prime} \mathrm{N}$ & $15^{\circ} 30^{\prime} \mathrm{E}$ & -12.3 & -16.7 & Yde et al. (2008) \\
\hline \multicolumn{7}{|l|}{ European Alps } \\
\hline Glacier de Tsanfleuron, Switzerland & 1994 & $46^{\circ} 20^{\prime} \mathrm{N}$ & $07^{\circ} 15^{\prime} \mathrm{E}$ & $\sim-7.8$ & -12.2 & Fairchild et al. (1999) \\
\hline Dammagletscher, Switzerland & 2008 & $46^{\circ} 38^{\prime} \mathrm{N}$ & $08^{\circ} 27^{\prime} \mathrm{E}$ & -13.3 & -17.3 & Hindshaw et al. (2011) \\
\hline Hintereisferner, Austria & $1969-1970$ & $46^{\circ} 49^{\prime} \mathrm{N}$ & $10^{\circ} 48^{\prime} \mathrm{E}$ & $\sim-13.8$ & $\sim-19.4$ & Behrens et al. (1971) \\
\hline Kesselwandferner, Austria & 1969-1970 & $46^{\circ} 50^{\prime} \mathrm{N}$ & $10^{\circ} 48^{\prime} \mathrm{E}$ & $\sim-14.8$ & $\sim-18.1$ & Behrens et al. (1971) \\
\hline \multicolumn{7}{|l|}{ Andes } \\
\hline Cordillera Blanca catchments, Peru & 2004-2006 & $9-10^{\circ} \mathrm{S}$ & $77-78^{\circ} \mathrm{W}$ & -13.3 & -15.3 & Mark and McKenzie (2007) \\
\hline Juncal River, Chile & 2011-2012 & $32^{\circ} 52^{\prime} \mathrm{S}$ & $70^{\circ} 10^{\prime} \mathrm{W}$ & $\sim-16.4$ & $\sim-18.0$ & Ohlanders et al. (2013) \\
\hline \multicolumn{7}{|l|}{ Asia } \\
\hline Hailuogou Glacier river, China & 2008-2009 & $29^{\circ} 34^{\prime} \mathrm{N}$ & $101^{\circ} 59^{\prime} \mathrm{E}$ & -13.7 & -17.6 & Meng et al. (2014) \\
\hline Kumalak Glacier no. 72 , China & 2009 & $41^{\circ} 49^{\prime} \mathrm{N}$ & $79^{\circ} 51^{\prime} \mathrm{E}$ & $-9.8^{\mathrm{a}}$ & & Kong and Pang (2012) \\
\hline Urumqi Glacier no. 1, China & 2009 & $43^{\circ} 07^{\prime} \mathrm{N}$ & $86^{\circ} 48^{\prime} \mathrm{E}$ & $-8.7^{\mathrm{a}}$ & & Kong and Pang (2012) \\
\hline
\end{tabular}

a Single sample.

of these studies are based on few samples. Hence, it therefore remains unknown whether a high spatial variability in $\delta^{18} \mathrm{O}$ is a common phenomenon or related to specific circumstances such as surge activity or presence of tributary glaciers.

\section{Discussion}

\subsection{Differences in $\delta^{18} O$ between the Mittivakkat Gletscher river and Kuannersuit Glacier river}

A significant difference between the $\delta^{18} \mathrm{O}$ dynamics in the Mittivakkat Gletscher river and Kuannersuit Glacier river is the marked diurnal oscillations in the former and the lack of a diurnal signal in the latter during the peak flow period. At the Mittivakkat Gletscher river, the 2004 hydrograph separation analysis showed a $3 \mathrm{~h}$ lag of $\delta^{18} \mathrm{O}$ to run-off caused by the difference in travel time for ice melt and snowmelt. Meltwater in the early melt season was dominated by snowmelt with relatively high $\delta^{18} \mathrm{O}$ and weak diurnal oscillations; whereas diurnal oscillations with amplitudes between 0.11 and $0.49 \%$ existed during the peak flow period due to mixing of a dominant ice melt component and a secondary snowmelt component. Diurnal oscillations in $\delta^{18} \mathrm{O}$ are common in meltwater from small, glacierised catchments; for instance, at Aus- tre Okstindbreen, Norway, the average diurnal amplitude is approximately $0.2 \%$ o (Theakstone, 1988, 2003; Theakstone and Knudsen, 1989, 1996a, b). The largest diurnal amplitudes in $\delta^{18} \mathrm{O}$ (up to $4.3 \%$ ) have been observed in smallscale GrIS catchments, such as at Imersuaq and "N Glacier", where large differences in $\delta^{18} \mathrm{O}$ exist between various ice facies and snowmelt (Yde and Knudsen, 2004; Bhatia et al., 2011).

The lack of strong diurnal oscillations as observed in the post-surge years at the Kuannersuit Glacier river indicates a mono-source system, a well-mixed drainage network or a multi-source system, where the primary components have similar $\delta^{18} \mathrm{O}$ compositions. The expected primary component, glacier ice melt, has lower $\delta^{18} \mathrm{O}$ than bulk run-off, and there must be additional contributions from basal ice melt (similar $\delta^{18} \mathrm{O}$ composition to run-off), snowmelt (unknown $\delta^{18} \mathrm{O}$ composition) or rainwater (higher $\delta^{18} \mathrm{O}$ composition than run-off). We therefore hypothesise that the presence of a well-mixed drainage network is the most likely reason for the observed $\delta^{18} \mathrm{O}$ signal in the bulk run-off from Kuannersuit Glacier. During the surge event the glacier surface became heavily crevassed and the pre-existing drainage system collapsed (Yde and Knudsen, 2005a). It is a generally accepted theory that the drainage system of surging glaciers trans- 
forms into a distributed network where meltwater is routed via a system of linked cavities (Kamb et al., 1985; Kamb, 1987), but little is known about how subglacial drainage systems evolve into discrete flow systems in the years following a surge event. In the initial quiescent phase at Kuannersuit Glacier, frequent loud noises interpreted as drainage system roof collapses were observed, in addition to episodic export of ice blocks from the portal, suggesting ongoing changes to the englacial and subglacial drainage system. A consequence of these processes is also visible on the glacier surface, where circular collapse chasms formed above marginal parts of the subglacial drainage system (Yde and Knudsen, 2005a).

Lack of diurnal oscillations in $\delta^{18} \mathrm{O}$ has previously been related to other causes at non-surging glaciers. At Glacier de Tsanfleuron, Switzerland, sampling in the late melt season (23-27 August 1994) showed no diurnal variations in $\delta^{18} \mathrm{O}$, which was interpreted by Fairchild et al. (1999) as a consequence of limited altitudinal range (less than $500 \mathrm{~m}$ ) of the glacier. An alternative explanation may be that snowmelt only constituted so small a proportion of the total run-off in the late melt season that discrimination between snowmelt and ice melt was impossible. At the glacier Killersuaq, an outlet glacier from the ice cap Amitsulooq in west Greenland, Andreasen (1984) found that diurnal oscillations in $\delta^{18} \mathrm{O}$ were prominent during the relatively warm summer of 1982, whereas no diurnal $\delta^{18} \mathrm{O}$ oscillations were observed in 1983 because the glacier was entirely snow-covered throughout the ablation season, due to low summer surface mass balance caused by the 1982 El Chichón eruption (Ahlstrøm et al., 2007).

\section{$5.2 \delta^{18} \mathrm{O}$ compositions in glacier rivers}

It is clear from the studies at Mittivakkat Gletscher and Kuannersuit Glacier that glacier rivers have different $\delta^{18} \mathrm{O}$ compositions. The bulk meltwater from Mittivakkat Gletscher has a $\delta^{18} \mathrm{O}$ composition similar to the water draining the nearby local glacier Hobbs Gletscher and to waters from studied valley and outlet glaciers in Scandinavia, Svalbard, the European Alps, the Andes and Asia (Table 3). The $\delta^{18} \mathrm{O}$ composition of Kuannersuit Glacier is lower and similar to the $\delta^{18} \mathrm{O}$ composition of the glacier Killersuaq (Table 3). Currently, the lowest $\delta^{18} \mathrm{O}$ compositions are found in bulk meltwater draining the GrIS in west Greenland (Table 3), but there is a lack of $\delta^{18} \mathrm{O}$ data from Antarctic rivers. Estimations of $\delta^{18} \mathrm{O}$ based on $\delta \mathrm{D}$ measurements suggest $\delta^{18} \mathrm{O}$ values of $-32.1,-34.4$ and $-41.9 \%$ in waters draining Wilson Piedmont Glacier, Rhone Glacier and Taylor Glacier, respectively (Henry et al., 1977).

The differences in $\delta^{18} \mathrm{O}$ in glacial rivers are due to a combination of geographical effects related to altitude, continentality and latitude (Dansgaard et al., 1973) and temporal effects that work on various timescales and in specific environments. These temporal effects include a seasonal effect (Dansgaard, 1964), a monsoonal effect (Tian et al., 2001;
Kang et al., 2002), a precipitation amount effect (Holdsworth et al., 1991) and a palaeoclimatic effect (Reeh et al., 2002). For instance, the altitude and continentality effects cause low $\delta^{18} \mathrm{O}$ in rivers draining the GrIS compared to rivers draining valley glaciers at similar latitudes (Table 3 ). More data on the $\delta^{18} \mathrm{O}$ composition and dynamics in glacial rivers are needed to improve the understanding of how the relative influence of geographical and temporal effects varies on local and regional scales.

\section{Conclusions}

In this study, we have examined the oxygen isotope hydrology in two of the most studied glacierised river catchments in Greenland to improve our understanding of the prevailing differences between contrasting glacial environments. This study has provided insights into the variability and composition of $\delta^{18} \mathrm{O}$ in river water draining glaciers and ice caps adjacent to the GrIS.

The following results were found:

- The Mittivakkat Gletscher river on Ammassalik Island, southeast Greenland, has a mean annual $\delta^{18} \mathrm{O}$ of $-14.68 \pm 0.18 \%$ during the peak flow period, which is similar to the $\delta^{18} \mathrm{O}$ composition in glacier rivers in Scandinavia, Svalbard, the European Alps, the Andes and Asia. The Kuannersuit Glacier river on the island Qeqertarsuaq, west Greenland, has a lower mean annual $\delta^{18} \mathrm{O}$ of $-19.47 \pm 0.55 \%$, which is similar to the $\delta^{18} \mathrm{O}$ composition in bulk meltwater draining an outlet glacier from the ice cap Amitsulooq but higher than the $\delta^{18} \mathrm{O}$ composition in bulk meltwater draining the GrIS.

- In the Mittivakkat Gletscher river the diurnal oscillations in $\delta^{18} \mathrm{O}$ were conspicuous. This was due to the presence of an efficient subglacial drainage system and diurnal variations in the ablation rates of snow and ice that had distinguishable oxygen isotope compositions. The diurnal oscillations in $\delta^{18} \mathrm{O}$ lagged behind the diurnal oscillations in run-off by approximately $3 \mathrm{~h}$. A hydrograph separation analysis revealed that the ice melt component constituted $82 \pm 5 \%$ of the total run-off and dominated the observed variations in total run-off during the peak flow period in 2004. The snowmelt component peaked between 10:00 and 13:00, reflecting the long travel time and a possibly inefficiently distributed subglacial drainage network in the upper part of the glacier.

- In contrast to the Mittivakkat Gletscher river, the Kuannersuit Glacier river showed no diurnal oscillations in $\delta^{18} \mathrm{O}$. This is likely a consequence of glacier surging. In the years following a major surge event, where Kuannersuit Glacier advanced $10.5 \mathrm{~km}$, meltwater was routed through a tortuous subglacial conduit network of linked 
cavities, mixing the contributions from glacier ice, basal ice, snow and rainwater.

- This study has shown that environmental and physical contrasts in glacier river catchments influence the spatio-temporal variability of the $\delta^{18} \mathrm{O}$ compositions. In Greenlandic glacier rivers, the variability in $\delta^{18} \mathrm{O}$ composition is much higher than previously known ranging from relatively high $\delta^{18} \mathrm{O}$ values in small-scale coastal glacierised catchments to relatively low $\delta^{18} \mathrm{O}$ values in GrIS catchments. This study demonstrates that water isotope analyses can be used to obtain important information on water sources and subglacial drainage system structure that is highly desired for understanding glacier hydrology.

\section{The Supplement related to this article is available online at doi:10.5194/hess-20-1197-2016-supplement.}

Acknowledgements. We thank all the students who have participated in the fieldwork over the years. We are also grateful to the University of Copenhagen for allowing us to use the facilities at the Arctic Station and Sermilik Station and to the Niels Bohr Institute, University of Copenhagen, for processing the isotope samples. We thank Andreas Peter Bech Mikkelsen and four reviewers for valuable comments on the manuscript.

Edited by: M. Hrachowitz

\section{References}

Ahlstrøm, A. P., Bøggild, C. E., Olesen, O. B., Petersen, D., and Mohr, J. J.: Mass balance of the Amitsulôq ice cap, West Greenland, IAHS-AISH P., 318, 107-115, 2007.

Andreasen, J.-O.: Ilt-isotop undersøgelse ved Kidtlessuaq, Vestgrønland, PhD Dissertation, Aarhus University, Aarhus, 33 pp., 1984.

Arendt, C. A., Aciego, A. M., and Hetland, E. A.: An open source Bayesian Monte Carlo isotope mixing model with applications in Earth surface processes, Geochem. Geophy. Geosy., 16, 12741292, doi:10.1002/2014GC005683, 2015.

Bales, R. C., Guo, Q., Shen, D., McConnell, J. R., Du, G., Burkhart, J. F., Spikes, V. B., Hanna, E., and Cappelen, J.: Annual accumulation for Greenland updated using ice core data developed during 2000-2006 and analysis of daily coastal meteorological data, J. Geophys. Res., 114, D06116, doi:10.1029/2008JD011208, 2009.

Bamber, J., van den Broeke, M., Ettema, J., Lenaerts, J., and Rignot, E.: Recent large increase in freshwater fluxes from Greenland into the North Atlantic, Geophys. Res. Lett., 39, L19501, doi:10.1029/2012GL052552, 2012.

Bárcena, T. G., Yde, J. C., and Finster, K. W.: Methane flux and high-affinity methanotrophic diversity along the chronosequence of a receding glacier in Greenland, Ann. Glaciol., 51, 23-31, 2010.

Bárcena, T. G., Finster, K. W., and Yde, J. C.: Spatial patterns of soil development, methane oxidation, and methanotrophic diversity along a receding glacier forefield, Southeast Greenland, Arct. Antarct. Alp. Res., 43, 178-188, 2011.

Behrens, H., Bergmann, H., Moser, H., Rauert, W., Stichler, W. Ambach, W., Eisner, H., and Pessl, K.: Study of the discharge of Alpine glaciers by means of environmental isotpes and dye tracers, Z. Gletscherkunde Glazialgeologie, 7, 79-102, 1971.

Behrens, H., Moser, H., Oerter, H., Rauert, W., and Stichler, W.: Models for the runoff from a glaciated catchment area using measurements of environmental isotope contents, in: Proceedings of the International Symposium on Isotope Hydrology, International Atomic Energy Agency, Vienna, 829-846, 1978.

Bhatia, M. P., Das, S. B., Kujawinski, E. B., Henderson, P., Burke, A., and Charette, M. A.: Seasonal evolution of water contributions to discharge from a Greenland outlet glacier: insight from a new isotope-mixing model, J. Glaciol., 57, 929-941, 2011.

Blaen, P. J., Hannah, D. M., Brown, L. E., and Milner, A. M.: Water source dynamics of high Arctic river basins, Hydrol. Process., 28, 3521-3538, 2014.

Bøggild, C. E., Brandt, R. E., Brown, K. J., and Warren, S. G.: The ablation zone in Northeast Greenland: ice types, albedos and impurities, J. Glaciol., 56, 101-113, 2010.

Box, J. E., Fettweis, X., Stroeve, J. C., Tedesco, M., Hall, D. K., and Steffen, K.: Greenland ice sheet albedo feedback: thermodynamics and atmospheric drivers, The Cryosphere, 6, 821-839, doi:10.5194/tc-6-821-2012, 2012.

Boye, B.: En undersøgelse af variationer i $\delta^{18} \mathrm{O}$-indholdet i prøver indsamlet på Mittivakkat gletscheren i Østgrønland, Ms Thesis, Aarhus University, Aarhus, 101 pp., 1999.

Cable, J., Ogle, K., and Williams, D.: Contribution of glacier meltwater to streamflow in the Wind River Range, Wyoming, inferred via a Bayesian mixing model applied to isotopic measurements, Hydrol. Process., 25, 2228-2236, doi:10.1002/hyp.7982, 2011.

Cappelen, J.: Weather observations from Greenland 1958-2012, Danish Meteorological Institute Technical Report 13-11, Danish Meteorological Institute, Copenhagen, 23 pp., 2013.

Coplen, T. B.: New guidelines for reporting stable hydrogen, carbon, and oxygen isotope-ratio data, Geochim. Cosmochim. Ac. 60, 3359-3360, 1996.

Dahlke, H. E., Lyom, S. W., Jansson, P., Karlin, T., and Rosquist, G.: Isotopic investigation of runoff generation in a glacierized catchment in northern Sweden, Hydrol. Process., 28, 1383-1398, 2014.

Dansgaard, W.: Stable isotopes in precipitation, Tellus, 16, 436468, 1964.

Dansgaard, W., Johnsen, S. J., Clausen, H. B., and Gundestrup, N.: Stable isotope glaciology, Medd. Grønland, 197, 53 pp., 1973.

Dinçer, T., Payne, B. R., Florkowski, T., Martinec, J., and Tongiorgi, E.: Snowmelt runoff from measurements of tritium and oxygen18, Water Resour. Res., 6, 110-124, 1970.

Dissing, L.: Studier af kemiske forhold i sne aflejret på og ved Mittivakkat-gletscheren i Østgrønland, Ms Thesis, Aarhus University, 102 pp., 2000.

Epstein, S. and Sharp, R. P.: Oxygen-isotope variations in the Malaspina and Saskatchewan Glaciers, J. Geol., 67, 88-102, 1959. 
Fairchild, I. J., Killawee, J. A., Sharp, M. J., Spiro, B., Hubbard, B., Lorrain, R., and Tison, J.-L.: Solute generation and transfer from a chemically reactive Alpine glacial-proglacial system, Earth Surf. Proc. Land., 24, 1189-1211, 1999.

Gat, J. R. and Gonfiantini, R.: Stable isotope hydrology. Deuterium and oxygen-18 in the water cycle, Technical Report Series 210, International Atomic Energy Agency, Vienna, 334 pp., 1981.

Haldorsen, S., Riise, G., Swensen, B., and Sletten, R. S.: Environmental isotopes as tracers in catchments, in: Geochemical processes, weathering and groundwater recharge in catchments, edited by: Saether, O. M. and de Caritat, P., Balkema, Rotterdam, 185-210, 1997.

Hambrey, M. J.: Oxygen isotope studies at Charles Rabots Bre, Okstindan, northern Norway, Geogr. Ann. A, 56, 147-158, 1974.

Hanna, E., Huybrechts, P., Janssens, I., Cappelen, J., Steffen, K., and Stephens, A.: Runoff and mass balance of the Greenland ice sheet: 1958-2003, J. Geophys. Res., 110, D13108, doi:10.1029/2004JD005641, 2005.

Hanna, E., Huybrechts, P., Steffen, K., Cappelen, J., Huff, R., Shuman, C., Irvine-Fynn, T., Wise, S., and Griffiths, M.: Increased runoff from melt from the Greenland ice sheet: A response to global warming, J. Climate, 21, 331-341, 2008.

Hanna, E., Mernild, S. H., Cappelen, J., and Steffen, K.: Recent warming in Greenland in a long-term instrumental (18812012) climatic context, Part 1: evaluation of surface air temperature records, Environ. Res. Lett., 7, 045404, doi:10.1088/17489326/7/4/045404, 2012.

Hanna, E., Jones, J. M., Cappelen, J., Mernild, S. H., Wood, L., Steffen, K., and Huybrechts, P.: Discerning the influence of North Atlantic atmospheric and oceanic forcing effects on 1900-2012 Greenland summer climate and melt, Int. J. Climatol., 33, 862888,2013

Hasholt, B. and Mernild, S. H.: Glacial erosion and sediment transport in the Mittivakkat Glacier catchment, Ammassalik Island, southeast Greenland, 2005, IAHS-AISH P., 306, 45-55, 2006.

Henry, C. H., Wilson, A. T., Popplewell, K. B., and House, D. A.: Dating of geochemical events in Lake Bonney, Antarctica, and their relation to glacial and climate changes, New Zeal. J. Geol. Geop., 20, 1103-1122, 1977.

Herschy, R. W.: Hydrometry: Principles and practice, 2nd edition, Wiley, 384 pp., 1999.

Hindshaw, R. S., Tipper, E. T., Reynolds, B. C., Lemarchard, E., Wiederhold, J. G., Magnusson, J., Bernasconi, S. M., Kretzschmar, R., and Bourdon, B.: Hydrological control of stream water chemistry in a glacial catchment (Damma Glacier, Switzerland), Chem. Geol., 285, 215-230, doi:10.1016/j.chemgeo.2011.04.012, 2011.

Hindshaw, R. S., Rickli, J., Leuthold, J., Wadham, J., and Bourdon, B.: Identifying weathering sources and processes in an outlet glacier of the Greenland Ice Sheet using $\mathrm{Ca}$ and $\mathrm{Sr}$ isotope ratios, Geochim. Cosmochim. Ac., 145, 50-71, 2014.

Hindshaw, R. S., Heaton, T. H. E., Boyd, E. S., Lindsay, M. R., and Tipper, E. T.: Influence of glaciation on mechanisms of mineral weathering in two high Arctic catchments, Chem. Geol., 420, 37-50, doi:10.1016/j.chemgeo.2015.11.004, 2016.

Holdsworth, G., Fogarasi, S., and Krouse, H. R.: Variation of the stable isotopes of water with altitude in the Saint Elias Mountains of Canada, J. Geophys. Res. 96, 7483-7494, 1991.
Hooper, R. P. and Shoemaker, C. A.: A comparison of chemical and isotopic hydrograph separation, Water Resour. Res., 106, 233244, 1986.

Humlum, O.: Late-Holocene climate in central West Greenland: meteorological data and rock-glacier isotope evidence, Holocene, 9, 581-594, 1999.

Kamb, B.: Glacier surge mechanism based on linked cavity configuration of the basal water conduit system, J. Geophys. Res., 92, 9083-9100, 1987.

Kamb, B., Raymond, C. F., Harrison, W. D., Engelhardt, H., Echelmeyer, K. A., Humphrey, N., Brugman, M. M., and Pfeffer, T.: Glacier surge mechanism: 1982-1983 surge of Variegated Glacier, Alaska, Science, 227, 469-479, 1985.

Kang, S., Kreutz, K. J., Mayewski, P. A., Qin, D., and Yao, T.: Stable-isotopic composition of precipitation over the northern slope of the central Himalaya, J. Glaciol., 48, 519-526, 2002.

Keegan, K. M., Albert, M. R., McConnell, J. R., and Baker, I.: Climate change and forest fires synergistically drive widespread melt events of the Greenland Ice Sheet, P. Natl. Acad. Sci. USA, 111, 7964-7967, 2014.

Kendall, C., Doctor, D. H., and Young, M. B.: Environmental isotope applications in hydrological studies, in: Treatise on Geochemistry, second edition, edited by: Holland, H. D. and Turekian, K. K., Elsevier, Oxford, 7, chapter 9, 273-327, 2014.

Knudsen, N. T., Yde, J. C., and Gasser, G.: Suspended sediment transport in glacial meltwater during the initial quiescent phase after a major surge event at Kuannersuit Glacier, Greenland, Geogr. Tidsskr., 107, 1-7, 2007.

Knudsen, N. T., Nørnberg, P., Yde, J. C., Hasholt, B., and Heinemeier, J.: Recent marginal changes of the Mittivakkat Glacier, Southeast Greenland and the discovery of remains of reindeer (Rangifer tarandus), polar bear (Ursus maritimus) and peaty material, Geogr. Tidsskr., 108, 137-142, 2008.

Kong, Y. and Pang, Z.: Evaluating the sensitivity of glacier rivers to climate change based on hydrograph separation of discharge, J. Hydrol., 434-435, 121-129, 2012.

Kristiansen, S. M., Yde, J. C., Bárcena, T. G., Jakobsen, B. H., Olsen, J., and Knudsen, N. T.: Geochemistry of groundwater in front of a warm-based glacier in Southeast Greenland, Geogr. Ann. A, 95, 97-108, 2013.

Larsen, N. K., Kronborg, C., Yde, J. C., and Knudsen, N. T.: Debris entrainment by basal freeze-on and thrusting during the 19951998 surge of Kuannersuit Glacier on Disko Island, west Greenland, Earth Surf. Proc. Land., 35, 561-574, 2010.

Lee, J., Feng, X., Faiia, A., Posmentier, E., Osterhuber, R., and Kirchner, J.: Isotopic evolution of snowmelt: A new model incorporating mobile and immobile water, Water Resour. Res., 46, W11512, doi:10.1029/2009WR008306, 2010.

Lutz, S., Anesio, A. M., Villar, S. E. J., and Benning, L. G.: Variations of algal communities cause darkening of a Greenland glacier, FEMS Microbiol. Ecol., 89, 402-414, 2014.

Mark, B. G. and Seltzer, G. O.: Tropical glacier meltwater contribution to stream discharge: a case study in the Cordillera Blanca, Peru, J. Glaciol., 49, 271-281, 2003.

Mark, B. G. and McKenzie, J. M.: Tracing increasing tropical Andean glacier melt with stable isotopes in water, Environ. Sci. Technol., 41, 6955-6960, 2007. 
McDonnell, J. J., Bonell, M., Stewart, M. K., and Pearce, A. J.: Deuterium variations in storm rainfall - implications for stream hydrograph separation, Water Resour. Res., 26, 455-458, 1990.

Meng, Y., Liu, G., and Zhang, L.: A comparative study on stable isotopic composition in waters of the glacial and nonglacial rivers in Mount Gongga, China, Water Environ. J., 28, 212-221, 2014.

Mernild, S. H.: The internal drainage system of the lower Mittivakkat Glacier, Ammassalik Island, SE Greenland, Geogr. Tidsskr., 106, 13-24, 2006.

Mernild, S. H. and Liston, G. E.: The influence of air temperature inversions on snowmelt and glacier mass balance simulations, Ammassalik Island, Southeast Greenland, J. Appl. Meteorol. Clim., 49, 47-67, 2010.

Mernild, S. H. and Liston, G. E.: Greenland freshwater runoff, Part II: Distribution and trends, 1960-2010, J. Clim., 25, 6015-6035, 2012.

Mernild, S. H., Hasholt, B., Jakobsen, B. H., and Hansen, B. U.: Meteorological observations 2006 and ground temperature variations over 12-year at the Sermilik Station, Ammassalik Island, Southeast Greenland, Geogr. Tidsskr., 108, 153-161, 2008a.

Mernild, S. H., Liston, G. E., and Hasholt, B.: East Greenland freshwater runoff to the Greenland-Iceland-Norwegian Seas 19992004 and 2071-2100, Hydrol. Process., 22, 4571-4586, 2008 b.

Mernild, S. H., Knudsen, N. T., Lipscomb, W. H., Yde, J. C., Malmros, J. K., Hasholt, B., and Jakobsen, B. H.: Increasing mass loss from Greenland's Mittivakkat Gletscher, The Cryosphere, 5, 341-348, doi:10.5194/tc-5-341-2011, 2011.

Mernild, S. H., Malmros, J. K., Yde, J. C., and Knudsen, N. T.: Multi-decadal marine- and land-terminating glacier recession in the Ammassalik region, southeast Greenland, The Cryosphere, 6, 625-639, doi:10.5194/tc-6-625-2012, 2012.

Mernild, S. H., Pelto, M., Malmros, J. K., Yde, J. C., Knudsen, N. T., and Hanna, E.: Identification of snow ablation rate, ELA, AAR and net mass balance using transient snowline variations on two Arctic glaciers, J. Glaciol., 59, 649-659, 2013a.

Mernild, S. H., Knudsen, N. T., Hoffman, M. J., Yde, J. C., Hanna, E., Lipscomb, W. H., Malmros, J. K., and Fausto, R. S.: Volume and velocity changes at Mittivakkat Gletscher, southeast Greenland, J. Glaciol., 59, 660-670, 2013 b.

Mernild, S. H., Hanna, E., Yde, J. C., Cappelen, J., and Malmros, J. K.: Coastal Greenland air temperature extremes and trends 18902010: annual and monthly analysis, Int. J. Climatol., 34, 14721487,2014

Mernild, S. H., Hanna, E., McConnell, J. R., Sigl, M., Beckerman, A. P., Yde, J. C., Cappelen, J., Malmros, J. K., and Steffen, K.: Greenland precipitation trends in a long-term instrumental climate context (1890-2012): evaluation of coastal and ice core records, Int. J. Climatol., 35, 303-320, $2015 \mathrm{a}$.

Mernild, S. H., Malmros, J. K., Yde, J. C., Wilson, R., Knudsen, N. T., Hanna, E., Fausto, R. S., and van As, D.: Albedo decline on Greenland's Mittivakkat Gletscher in a warming climate, Int. J. Climatol., 35, 2294-2307, 2015 b.

Milner, A. M., Brown, L. E., and Hannah, D. M.: Hydroecological response of river systems to shrinking glaciers, Hydrol. Process., 23, 62-77, 2009.

Moser, H. and Stichler, W.: Environmental isotopes in ice and snow, in: Handbook of environmental isotope geochemistry, The terrestrial environment, A, edited by: Fritz, P. and Fontes, J. C., Elsevier, Amsterdam, Volume 1, 141-178, 1980.
Nghiem, S. V., Hall, D. K., Mote, T. L., Tedesco, M., Albert, M. R., Keegan, K., Shuman, C. A., DiGirolamo, N. E., and Neumann, G.: The extreme melt across the Greenland ice sheet in 2012, Geophys. Res. Lett., 39, L20502, doi:10.1029/2012GL053611, 2012.

Ohlanders, N., Rodriguez, M., and McPhee, J.: Stable water isotope variation in a Central Andean watershed dominated by glacier and snowmelt, Hydrol. Earth Syst. Sci., 17, 1035-1050, doi:10.5194/hess-17-1035-2013, 2013.

Penna, D., Engel, M., Mao, L., Dell'Agnese, A., Bertoldi, G., and Comiti, F.: Tracer-based analysis of spatial and temporal variations of water sources in a glacierized catchment, Hydrol. Earth Syst. Sci., 18, 5271-5288, doi:10.5194/hess-18-52712014, 2014.

Raben, P. and Theakstone, W. H.: Changes of ionic and oxygen isotopic composition of the snowpack at the glacier Austre Okstindbreen, Norway, 1995, Nord. Hydrol., 29, 1-20, 1998.

Reeh, N., Oerter, H., and Thomsen, H. H.: Comparison between Greenland ice-margin and ice-core oxygen-18 records, Ann. Glaciol., 35, 136-144, 2002.

Roberts, D. H., Yde, J. C., Knudsen, N. T., Long, A. J., and Lloyd, J. M.: Ice marginal dynamics and sediment delivery mechanisms during surge activity, Kuannersuit Glacier, Disko Island, West Greenland, Quaternary Sci. Rev., 28, 209-222, 2009.

Rodriguez, M., Ohlanders, N., and McPhee, J.: Estimating glacier and snowmelt contributions to stream flow in a Central Andes catchment in Chile using natural tracers, Hydrol. Earth Syst. Sci. Discuss., 11, 8949-8994, doi:10.5194/hessd-11-8949-2014, 2014.

Tedesco, M., Serreze, M., and Fettweis, X.: Diagnosing the extreme surface melt event over southwestern Greenland in 2007, The Cryosphere, 2, 159-166, doi:10.5194/tc-2-159-2008, 2008.

Tedesco, M., Fettweis, X., van den Broeke, M. R., van de Wal, R. S. W., Smeets, C. J. P. P., van de Berg, W. J., Serreze, M. C., and Box, J. E.: The role of albedo and accumulation in the 2010 melting record in Greenland, Environ. Res. Lett., 6, 014005, doi:10.1088/1748-9326/6/1/014005, 2011.

Theakstone, W. H.: Temporal variations of isotopic composition of glacier-river water during summer: observations at Austre Okstindbreen, Okstindan, Norway, J. Glaciol., 34, 309-317, 1988.

Theakstone, W. H.: Oxygen isotopes in glacier-river water, Austre Okstindbreen, Okstidan, Norway, J. Glaciol., 49, 282-298, 2003.

Theakstone, W. H.: Dating stratigraphic variations of ions and oxygen isotopes in a high-altitude snowpack by comparison with daily variations of precipitation chemistry at a low-altitude site, Hydrol. Res., 39, 101-112, 2008.

Theakstone, W. H. and Knudsen, N. T.: Temporal changes of glacier hydrological systems indicated by isotopic and related observations at Austre Okstindbreen, Okstindan, Norway, 1976-87, Ann. Glaciol., 13, 252-256, 1989.

Theakstone, W. H. and Knudsen, N. T.: Isotopic and ionic variations in glacier river water during three contrasting ablation seasons, Hydrol. Process., 10, 523-539, 1996 a.

Theakstone, W. H. and Knudsen, N. T.: Oxygen isotope and ionic concentrations in glacier river water: multi-year observations in the Austre Okstindbreen basin, Norway, Nord. Hydrol., 27, 101116, $1996 \mathrm{~b}$.

Tian, L., Masson-Delmotte, V., Stiévenard, M., Yao, T., and Jouzel, J.: Tibetan Plateau summer monsoon northward extent revealed 
by measurements of water stable isotopes, J. Geophys. Res., 106, 28081-28088, 2001.

van As, D., Hubbard, A. L., Hasholt, B., Mikkelsen, A. B., van den Broeke, M. R., and Fausto, R. S.: Large surface meltwater discharge from the Kangerlussuaq sector of the Greenland ice sheet during the record-warm year 2010 explained by detailed energy balance observations, The Cryosphere, 6, 199-209, doi:10.5194/tc-6-199-2012, 2012.

Vaughan, D. G., Comiso, J. C., Allison, J., Carrasco, J., Kaser, G., Kwok, R., Mote, P., Murray, T., Paul, F., Ren, J., Rignot, E., Solomina, O., Steffen, K., and Zhang, T.: Observations: Cryosphere, in: Climate Change 2013: The physical science basis, Contribution of working group I to the Fifth Assessment Report of the Intergovernmental Panel on Climate Change, edited by: Stocker, T. F., Qin, D., Plattner, G.-K., Tignor, M., Allen, S. K., Boschung, J., Nauels, A., Xia, Y., Bex, V., and Midgley, P. M., Cambridge University Press, Cambridge, United Kingdom and New York, NY, USA, 2013.

Weidick, A. and Morris, E.: Local glaciers surrounding the continental ice sheets, in: Into the second century of world glacier monitoring - prospects and strategies, edited by: Haeberli, W., Hoelzle, M., and Suter, S., UNESCO Studies and Reports in Hydrology, 56, 167-176, 1998.

Yallop, M. L., Anesio, A. M., Perkins, R. G., Cook, J., Telling, J., Fagan, D., MacFarlene, J., Stibal, M., Barker, G., Bellas, C., Hodson, A., Tranter, M., Wadham, J., and Roberts, N. W.: Photophysiology and albedo-changing potential of the ice algal community on the surface of the Greenland ice sheet, ISME J., 6 , 2302-2313, 2012.

Yde, J. C. and Knudsen, N. T.: The importance of oxygen isotope provenance in relation to solute content of bulk meltwaters at Imersuaq Glacier, West Greenland, Hydrol. Process., 18, 125139, 2004.
Yde, J. C. and Knudsen, N. T.: Glaciological features in the initial quiescent phase of Kuannersuit Glacier, Greenland, Geogr. Ann. A, 87, 473-485, 2005a.

Yde, J. C. and Knudsen, N. T.: Observations of debris-rich naled associated with a major glacier surge event, Disko Island, West Greenland, Permafrost Periglac., 16, 319-325, 2005 b.

Yde, J. C. and Knudsen, N. T.: 20th-century glacier fluctuations on Disko Island (Qeqertarsuaq), Greenland, Ann. Glaciol., 46, 209214, 2007.

Yde, J. C., Knudsen, N. T., and Nielsen, O. B.: Glacier hydrochemistry, solute provenance, and chemical denudation at a surge-type glacier in Kuannersuit Kuussuat, Disko Island, West Greenland, J. Hydrol., 300, 172-187, 2005a.

Yde, J. C., Knudsen, N. T., Larsen, N. K., Kronborg, C., Nielsen, O. B., Heinemeier, J., and Olsen, J.: The presence of thrustblock naled after a major surge event: Kuannersuit Glacier, West Greenland, Ann. Glaciol., 42, 145-150, 2005b.

Yde, J. C., Riger-Kusk, M., Christiansen, H. H., Knudsen, N. T., and Humlum, O.: Hydrochemical characteristics of bulk meltwater from an entire ablation season, Longyearbreen, Svalbard, J. Glaciol., 54, 259-272, 2008.

Yde, J. C., Hodson, A. J., Solovjanova, I., Steffensen, J. P., Nørnberg, P., Heinemeier, J., and Olsen, J.: Chemical and isotopic characteristics of a glacier-derived naled in front of Austre Grønfjordbreen, Svalbard, Polar Res., 31, 17628, doi:10.3402/polar.v31i0.17628, 2012.

Yde, J. C., Kusk Gillespie, M., Løland, R., Ruud, H., Mernild, S. H., de Villiers, S., Knudsen, N. T., and Malmros, J. K.: Volume measurements of Mittivakkat Gletscher, Southeast Greenland, J. Glaciol., 60, 1199-1207, 2014.

Zhou, S., Wang, Z., and Joswiak, D. R.: From precipitation to runoff: stable isotopic fractionation effect of glacier melting on a catchment scale, Hydrol. Process., 28, 3341-3349, 2014. 